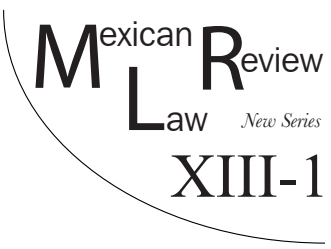

\title{
CHALLENGES OF COMPENSATION AND REPARATION FOR LOSS AND DAMAGE RELATED TO THE ADVERSE EFFECTS OF CLIMATE CHANGE
}

\author{
Jorge Gabriel Arévalo García*
}

\begin{abstract}
Anthropogenic climate change has and will have unavoidable adverse effects despite mitigation and adaptation policies. Therefore, the financial burden of the costs of loss and damage must be distributed fairly and proportionally. This implies that those responsible for climate change must take responsibility and compensate those who suffer losses and, if possible, repair the damages related to this phenomenon. However, climate justice has been limited by the lack of a causal link between a specific climate change effect and specific damages or losses. Accordingly, this article discusses the compensation and reparation of losses and damages related to the adverse effects of climate change, as a stream applicable after mitigation and adaptation policies. In addition, this article reviewes the implications of the relevant findings that established the existence and development of climate change as a problem that affects the enjoyment of human rights, to argue how the theory of human rights can contribute to the current legal model for reparation and compensation for losses and damages associated with climate change. Also, due to the impossibility of obtaining a legally binding agreement as a structure for integration, and to adequately address the problem of causes, consequences, benefits and burdens, vulnerable groups ought to be the most affected.
\end{abstract}

KEYWORDS: Loss and damage, reparation, compensation, attribution, causal nexus, Human Rights.

Resumen: El cambio climático antropogénico tiene y tendrá efectos adversos inevitables a pesar de las políticas de mitigación y adaptación. Esto implica que la carga financiera de los costos de pérdidas y daños debe distribuirse de manera justa y proporcional. Los responsables del cambio climático deben asumir la responsabilidad y compensar a quienes sufren pérdidas y, si es posible, reparar los daños relacionados con este fenómeno. Sin embargo, la justicia climática se ha visto limitada por la falta de un vínculo causal entre un evento

* Visiting Researcher at the Walther Schücking Institute for International Law of Christian-Albrechts-Universität Zu Kiel. Email: arevalo.garcia.jg@gmail.com. 
especifico de cambio climático y daños o pérdidas especificas. Este artículo aborda la compensación y reparación de pérdidas y daños relacionados con los efectos adversos del cambio climático, como una corriente aplicable después de las políticas de mitigación y adaptación. Asimismo, este artículo revisa las implicaciones de hallazgos relevantes que establecieron la existencia y el desarrollo del cambio climático como un problema que tiene implicaciones negativas para el disfrute de los derechos humanos, para argumentar cómo la teoría de los derechos humanos puede contribuir al modelo legal actual de reparación y compensación por daños y perjuicios ambientales. Además, debido a la imposibilidad de obtener un acuerdo legalmente vinculante como una estructura para la integración y para abordar adecuadamente el problema de las causas, consecuencias, beneficios y cargas, los grupos vulnerables serán los más afectados.

Palabras clave: Pérdidas y daños, reparación, compensación, atribución, nexo causal y derechos humanos.

\section{TABLE of Contents}

I. INTRODUCTION

II. Summary of the Science of Climate Ghange

III. Compensation for Loss and Damage Related to the Adverse Effects of Glimate Ghange

1. The Third Aspect of Climate Change Applicable After the Mitigation and Adaptation Policies.....

2. The Attribution and the Causal Link of Climate Change

IV. The theory of Human Rights and Compensation for

Damages and Losses Related to Climate Ghange.

V. Conclusions

\section{INTRODUCTION}

The vulnerability of humans and ecosystems to the impacts of climate change has increased the debate on the efficiency and effectiveness of national and international responses to mitigate and adapt to this global issue. For many countries located in the Intertropical Convergence Zone (ITCZ), the climatic threats refer to the changes in the volume of precipitation and the rise of temperature. ${ }^{1}$ With these observed trends, the intensity and frequency of hydrometeorological hazards are expected to increase, such as droughts, heat waves, hurricanes, tropical storms, floods, among others. These disturbances

1 Michael P. Byrne et al., Response of the Intertropical Convergence Zone to Climate Change: Location, Width, and Strength, 4 Current Climate Change Reports 355, 370 (2018). 
are affecting the resilience of many ecosystems, which is likely to be overcome. $^{2}$

Some of the negative climate effects on environmental and human systems have an impact on biodiversity, marine and coastal systems, forests, hydrology and water resources, the volume's decrease of groundwater storage, the generation of electricity, agriculture, soils, food, safety and human health. ${ }^{3}$ Therefore, the availability of free water will be reduced, affecting the human right to water. Also, the increase in droughts will shrink food production, affecting the human right to food. ${ }^{4}$ The rise of temperature alters the habitats and reproductive cycles, as well as species mobility, resulting in more poverty and human migration. Moreover, these environmental impacts will have consequences on the local economy, because it will change the location and behavior of species of commercial importance for local communities. The rights to life and health are being violated by the rise of temperatures, as well as changes in precipitation patterns and humidity, which consequently increase the transmission of vector diseases. ${ }^{5}$

The climatic impacts mentioned in the previous paragraphs result in losses and damages in economies, society, and natural resources, which must be compensated and repaired. In these circumstances, legal issues have emerged to demand compensation and reparation: "States shall develop national law regarding liability and compensation for the victims of pollution and other environmental damage. States shall also co-operate in an expeditious and more determined manner to develop further international law regarding liability and compensation for adverse effects of environmental damage caused by activities within their jurisdiction or control to areas beyond their jurisdiction" ${ }^{6}$ However, most attempts to develop an international or national law have been limited by the lack of a causal link between the causes and effects of climate change. Therefore, this article discusses how the causal link, the theory of attribution, and the theory of human rights, have a connection to demand binding obligations to repair and compensate the losses and damages of the adverse effects of climate change.

2 Andreas Fischlin et al., Ecosystems, their Properties, Goods, and Services, in Impacts, AdaPtation and Vulnerability. Contribution of Working Group II to the Fourth Assessment Report of the Intergovernmental Panel on Climate Change 21 1, 272 (Cambridge University Press) (2007).

3 Id.

4 Ulisses Confalonieri et al., Human Health, in Climate Change 2007: Impacts, Adaptation and Vulnerability. Contribution of Working Group II to the Fourth Assessment Report of the Intergovernmental Panel on Climate Change 391, 431 (Cambridge University Press) (2007).

5 Id.

6 U. N. The Rio Declaration on Environment and Development principle 13 (1992). 


\section{Summary of the Science of Glimate Ghange}

The lack of recognition to the existence of climate change, used to be a limitation for creating a national and international regulatory framework to address this global problem. Furthermore, scientific uncertainty has been used as an argument to reject or not acquire specific commitments assigning responsibilities to pay the costs that result from climate change. Additionally, natural climate variability over long periods of time has been used to deny that current climate change results from human activities. It was during, and after the industrial revolution that climate changes occur suddenly. With the record of an increase of greenhouse gases (GHGs) in the atmosphere, it was possible to establish that climate change is real, and a result of human activities carried out in developed countries. ${ }^{7}$ However, establishing that the Earth's climate system is changing abruptly was not always determined using computers and satellites. Therefore, it is important to analyze, to a certain extent, the path taken by the climate sciences to explain how, through the efforts of several scientists, it has been demonstrated that human activities have an effect on the climate system and, consequently, they are transforming ecosystems and the enjoyment of human rights.

The oldest records, that can be found in mythologies and legends, of climatic fluctuations date from approximately 3,000 years before Christ (BC). As catastrophic examples we can find the annual floods of the Nile; droughts with effects on food; long snowy winters that affected biodiversity, among others. Being part of ancestral legends, it is difficult to establish with certainty that these were climatic catastrophes, but they are fragments of the history of the world and are relevant when this problem is addressed. ${ }^{8}$ In particular, it was Aristotle in Greece who introduced the term Meteorology and made the first treatise dedicated exclusively to the atmosphere, consisting of four books known as Meteorology, and written around the year 340 BC. Moreover, the diary of Claudius Ptolemaeus, written around the year 120 after Christ $(\mathrm{AC})$ in Alexandria, is of great value because it recorded observations made for 171 days. Also, W. Haller kept weather records from 1546 to 1576, published later in 1872, and analyzed in $1949 .{ }^{9}$ That kind of research has

7 "Since the beginning of the industrial revolution, when people began burning fossil fuels, atmospheric concentrations of carbon dioxide (CO2) - the principal green-house gas (GHG) - have risen from about 280 parts per million (ppm) to more than 400 ppm, higher than at any time in the last 800,000 years" Daniel Bodansky et al., International Glimate Change Law 1 (Oxford University Press) (2017).

8 Hubert Horace Lamb, Climate, Present, Past and Future. Volume 2, Climatic HisTORY AND THE Future 1, 2 (Methuen and Co. Ltd.) (1977). An Indian mythology tells of a period in which it rained for 12 years.

9 Thomas Gale Moore, Glimate of Fear why we Shouldn't Worry about Global WARMing 46 (Cato Institute Washington, D.C.) (1998). 
shown, that warmer climate is accompanied by more rainfall due to greater evaporation. ${ }^{10}$

The period where meteorological observations began to be measured using instruments emerged with the creation of the thermometer by Galileo Galilei in 1597, in connection with the invention of the barometer by Torricelli in 1643, and the anemometer created by Leon Battista Alberti and others. From 1654 to 1670 the Accademia del Cimento (Academy of Experiment) was created in Florence to make meteorological observations. Shortly after, in 1723 a Scheme for the collection of standardized weather reports was organized by James Jurin, under the auspices of the Royal Society, which was responsible for taking the daily records of meteorological observations to develop a timeline. Furthermore, another major source of data was provided by the Societas Meteorologica Palatina, founded at Mannheim in $1780 .{ }^{11}$

The first daily weather maps were drawn by H. W. Brandes in 1820 from the observations made at the Mannheim network for the year 1783. With the invention of the electric telegraph in 1850, it was possible to track the movement of storms and warn people about them. ${ }^{12}$ In several countries, the printing of maps of daily weather reports continued by 1873. Meanwhile, in New York, W. C. Redfield developed the first hurricane maps. As for the measurements of sea surface temperature, it is presumed that ships began to measure it around 1780. During the last years of the nineteenth century, observations and records of the climate were made systematically around the planet. ${ }^{13}$

During the year 1872 in Leipzig, Germany, a group of 52 meteorologists analyzed the possibility of creating an international cooperation mechanism in meteorology. The Professor Buys Ballot, then director of the Royal Netherlands Meteorological Institute, proposed in his essay "Suggestions on a uniform system of meteorological observations" an agreement for a uniform standardization of methods and meteorological observation units, as well as, a proposal to facilitate the exchange of weather information at the international level. ${ }^{14}$

The First International Meteorological Congress was held at Vienna in 1873, which resulted in a Permanent Meteorological Committee, composed of seven prestigious meteorologists, the President was the Professor Buys Bellot. The principal task of this committee was to draft the rules and statutes of an international meteorological organization. In 1879, the International

10 Stuart Houston et al., Eighteenth-Century Naturalists of Hudson Bay 114 (McGill-Queen's University Press) (2003).

11 J. A. Kington, The Societas Meteorologica Palatina: An Eighteenth-Century Meteorological Society, 20 (11) WEATHER 416, 426 (1974).

12 H. H. Lamb, Climate, History and Modern World 318 (Routledge 1995) (1982).

13 Hubert Horace Lamb, Glimate, Present, Past and Future. Volume 2, Climatic HisTORY AND THE Future, supra note 8 at 23, 27.

14 World Meteorological Organization, History OF IMO, https://public.wmo.int/en/aboutus/who-we-are/history-IMO. 
Meteorological Organization (IMO) was created during the International Meteorological Congress held at Rome, it remained working until 1950, the year in which the IMO officially became the World Meteorological Organization (WMO). ${ }^{15}$

In this context, in 1824, Joseph Fourier argued that the temperature of the Earth can increase by the interposition of the atmosphere. Years after, in 1836, Pouillet explained that the atmospheric stratum absorbs more the terrestrial rays than solar radiation, although it was not known which component of the atmosphere was responsible for that phenomenon. ${ }^{16}$ In 1859 , John Tyndall identified that an increase in the radioactive components of the atmosphere could produce changes in the climate system. From 1873 to 1881, Köppen proposed that the examination of the annual average temperature of different latitudes was an adequate technique to obtain a global temperature. ${ }^{17}$ Also, Svante Arrehnius identified an interaction between the heat retention effects of carbon dioxide $(\mathrm{CO} 2)$ and water steam. ${ }^{18}$

In 1938 Guy Stewart Callendar, using information provided by World Weather Records, produced a series of global temperatures which helped to realize what the influence of carbon dioxide on temperature is. ${ }^{19}$ Callendar solved a set of equations that linked greenhouse gases and climate change, establishing that by doubling the atmospheric CO2 the global average temperature would increase by $20 \mathrm{C}$, with greater warming at the poles. He linked this phenomenon with the burning of fossil fuels and its impact on the natural greenhouse effect. Moreover, Callendar said that the composition of the atmosphere is changing at an exceptional speed in geological time scales. ${ }^{20}$

The measurements of $\mathrm{CO} 2$ concentrations in the atmosphere were initiated by Charles David Keeling in 1958, the results were well-documented changes in the composition of the atmosphere, information considered iconic in the science of climate change. Therefore, an increase of CO2 in the atmosphere due to the burning of fossil fuels was taken as evidence to show the effects of human activities on the overall composition of the atmosphere. ${ }^{21}$

Nevertheless, the idea that $\mathrm{CO} 2$ is important to determine global changes in temperature, and that human activities have been responsible for changes in $\mathrm{CO} 2$ levels in the atmosphere, arose under the skepticism of many sci-

$15 I d$.

16 Hervé Le Treut et al., Historical Overview of Climate Change Science, in Contribution of Working Group I to the Fourth Assessment Report of the Intergovernmental Panel on Chimate Change 93, 127 (Cambridge University Press) (2007).

17 Id.

18 Hanna Knox, Thinking Like a Climate, 16 Issue 1: Political Materials: Rethinking Environment, Remaking Theory, Distiktion; Journal of Social Theory 91, 109 (2015).

19 In 1923 the World Weather Records was created, it gathered data about temperature, precipitation and pressure from hundreds of stations around the world.

20 Hervé Le Treut et al., Historical Overview of Climate Change Science, supra note 16 at 100-102.

$21 \quad I d$. 
entists. $^{22}$ It was with the invention of the radiosonde in the decade of 1930 to 1940 , and with the invention of computer models, that meteorological science advanced in the analysis of great climate changes. The discovery of components such as Carbon 14 also helped, as well as the possibility to make precise observations in the atmosphere with pressure, temperature and humidity measurement. Finally, the analysis of great climate changes was reinforced describing the behavior of the atmospheric circulation in the hemispheres, alongside the operation of the laws that govern the development and direction of cyclones. ${ }^{23}$ Around 1970, other gases such as CH4, N2O and CFC, were recognized as important greenhouse gases. In 1990, greenhouse gases found in the atmosphere were higher than at any other time during the last half million years. Finally, with the development of satellites at the end of the 1950 s, the networks of planetary observations became a reality. ${ }^{24}$

Therefore, works and discoveries were oriented to the detection of climatic changes, to the attribution of the causes to the changes, and to predict what the effects of the changes in the climate would be. As for detection "... it is the process of demonstrating that the climate has changed in some definite statistical sense, without providing a reason for that change. The attribution of the causes of climate change is the process of establishing the most probable causes of the detected change with a defined level of confidence". ${ }^{25}$

Finally, as already mentioned, there were several attempts to organize meteorological observations to explain how and why the climate system is suddenly changing. However, these findings were considered important as a confirmation that sudden changes in the climate system have a negative impact on ecosystems and human beings. Furthermore, the development of climate change knowledge is crucial to determine who is responsible for paying the costs of the current global warming.

\section{Compensation for Loss and Damage Related to the Adverse Effects of Glimate Change}

\section{The Third Aspect of Climate Change Applicable After the Mitigation and Adaptation Policies}

The first international debates to recognize climate change as a global environmental problem, emphasized in taking measures and promote policies for climate change mitigation, mainly to reduce the emissions of Greenhouse

22 Hanna Knox, Thinking Like a Climate, supra note 18.

23 Hubert Horace Lamb, Glimate, Present, Past and Future. Volume 2, Glimatic HisTORY AND THE FUTURE, supra note 8 at 23, 27.

24 Id.

25 Id. 
Gases, and advocate towards climate change adaptation, adjusting infrastructure and public institutions to reduce the causes that result in climate change, providing for that purpose the conditions to resist the adverse effects. Such policies were established in the United Nations Framework Convention on Climate Change in 1992.

However, recognizing that anthropogenic climate change has and will have unavoidable adverse effects despite mitigation and adaptation policies, implies that the financial burden of the costs of losses and damages must be distributed fairly and proportionally. Those responsible for climate change should take responsibility compensating those who suffer the losses and, if possible, repair the damages related to this phenomenon. In this context, it has been suggested to address compensation and reparation for losses and damages related to the adverse effects of climate change, despite of mitigation and adaptation policies. ${ }^{26}$

The proposal of this third aspect of climate change has been developed considering the contributions of countries such as the Alliance of Small Island States (OASIS), with the recognition of principles of equity, international cooperation, as well as the identification of common but differentiated responsibilities, and respective capabilities. These actions encouraged the international community to adopt the Bali Action Plan (BAP) in 2007 and the Cancun Adaptation Framework (CAF) in 2010. In the BAP, the Conference of the Parties (COP) came to an agreement could, as a part of "enhanced action on adaptation", to consider addressing the losses and damages associated with the impacts of change climate change in developing countries, mostly those particularly vulnerable to the adverse effects of climate change. ${ }^{27}$ As a result, in 2013, the Warsaw International Mechanism for the losses and damages associated with the impacts of climate change was adopted.

To establish the Warsaw International Mechanism for Loss and Damage associated with Climate Change Impacts (Loss and Damage Mechanism), it was important to recognize that the adverse effects of climate change taken into consideration, included those that cannot be reduced through adaptation and mitigation policies. ${ }^{28}$ The three major functions of the mechanism are: a) Enhancing knowledge and understanding of comprehensive risk management approaches to address loss and damage associated with the adverse effects of climate change, including slow onset impacts. b) Strengthening dialogue, coordination, coherence and synergies among relevant stakeholders. $c$ ) Enhancing action and support, including finance, technology and capacitybuilding, to address loss and damage associated with the adverse effects of

26 Edward A Page \& Clare Heyward, Compensating for Climate Change Loss and Damage, 65 (2) Political Studies 356, 372 (2016).

27 Benoit Mayer, The International Law on Climate Ghange 184 (Cambridge University Press) (2018).

28 Id. 
climate change, which enable countries to undertake actions pursuant to decision 3/CP.18, paragraph 6.29

Also, article 8 of the Paris Agreement mentions the importance of dealing with losses and damages related to the adverse effects of climate change through the Loss and Damage Mechanism. ${ }^{30}$ The problem with the Paris Agreement and the Damage Mechanism is that they have gaps to establish specific rules, for example, on establishing why, how, when and who is obliged to bear the financial burden of losses and damages related to the adverse effects of climate change. This problem results from two major aspects: A) To quantify and value the losses and damages to determine the total amount of compensation or reparation. B) To establish the causal links (cause-effect relationship) to decide who is responsible for bearing the financial burden. Nevertheless, as Page and Heyward mentioned, the Loss and Damage Mechanism has yet to specify how assistance will be provided or how the international finance will be transferred. Also, the Paris Agreement advocated for the Loss and Damage Mechanism do not establish who should finance it. ${ }^{31}$

In terms of losses and damages related to climate change, it ought to be considered as a plausible definition what was stated by the 2012 Framework Convention on Climate Change: "the actual and/or potential manifestation of impacts associated with climate change in developing countries that negatively affect human and natural systems". ${ }^{32}$ Specifically, losses are defined as "negative impacts in relation to which reparation or restoration is impossible, such as loss of freshwater resources", ${ }^{33}$ and damage as "negative impacts in relation to which reparation or restoration is possible, such as windstorm damage to the roof of a building, or damage to a coastal mangrove forest as a result of coastal surges". ${ }^{34}$ In the United Nations Framework Convention on Climate Change, loss and damage are equivalent to the adverse effects of climate change defined as: "means changes in the physical environment or biota resulting from climate change which have significant deleterious effects on the composition, resilience or productivity of natural and managed ecosystems or on the operation of socio-economic systems or on human health and welfare" ${ }^{35}$ Furthermore, the inequalities of climate change are the result of determining who causes climate change (emitters of greenhouse gases), who

29 C.P. De. 2/CP. 19, 6 Doc. FCGC/CP/2013/10/Add.1 (Jan. 31, 2014).

30 The Paris Agreement art. 8, Dec. 12, 2015, U.N.F.G.G.C/CP.

31 Edward A Page \& Clare Heyward, Compensating for Climate Change Loss and Damage, supra note 26 .

32 Framework Convention on Climate Change, Subsidiary Body for Implementation, 37, A literature review on the topics in the context of thematic area 2 of the work programme on loss and damage: a range of approaches to address loss and damage associated with the adverse effects of climate change, U.N. Doc. FGCG/SBI/2012/INF. 14 (Nov. 15, 2012).

$33 I d$.

$34 \quad I d$.

35 United Nations Framework Convention on Climate Change art. 1, Jun. 4, 1992, U.N. 
receives the benefits, and who suffers the negative consequences. ${ }^{36}$ Thus, the problems are legal, philosophical, ethical, political and economic. Developing countries emit less greenhouse gases, however, they do not adapt to climate change and receive less benefits. One way to solve these problems is through compensation or reparation to restore the conditions or wealth to what it was before the interruption or the harm occurred. ${ }^{37}$

Regarding climate compensation methods, Page and Heyward quoting Goodin R., mention two methods: a) means-based compensation, b) endsbased compensation. ${ }^{38}$ According to Pages and Heyward, the compensation based on the means has the objective of leaving the agents in the same conditions they had before suffering the damages and the losses, restoring partially or totally the affected goods. Through this method we seek to repair, restore or replace an affected medium, which could be possible through the financial funds allocated for this purpose. Page and Heyward give the following case: "compensation is a financial award from an international compensatory fund or commission to an individual farmer for the purpose of replacing livestock or equipment after a climate change-related storm surge seriously damages their farm". ${ }^{39}$ In some cases it is impossible to make a compensation or repair. In this cases, Page and Heyward mention that it is convenient to use "Satisfaction" measures. Within these measures are "Public apologies and commemoration, as well as reconciliation initiatives". ${ }^{40}$

In summary, climate compensatory approaches respond to losses and damages related to the adverse effects of climate change, making those affected able to integrate or recover the conditions, means and ends, in an equal or comparable state they had before adverse effects occur. These methods have obstacles that we can find in the characteristics that are generally used to describe climate change: global, progressive, unequal, urgent, etc.

\section{The Attribution and the Causal Link of Climate Change}

The compensatory models described above have been rejected by many policy makers, arguing that although it has been demonstrated with a high level of certainty that the current climate change is anthropogenic, it is not possible to demonstrate that climate change is the only cause of specific losses and damages. As catastrophic events often occur as a result of natural climat-

36 Bridget Lewis, Environmental Human Rights and Guimate Ghange. Gurrent Status and Future Prospects, Springer 151 (Queensland University of Technology) (2018).

37 Edward A Page \& Clare Heyward, Compensating for Climate Change Loss and Damage, supra note 26 .

38 Id.

39 Id.

40 Id. 
ic variability, the problem of attribution and causality emerges, on whether it is a result of human activities or from nature.

In these circumstances, the traditional legal processes to demand redress and compensation require attribution, and the latter requires causality. At the international level, a country shall demonstrate that an adverse effect associated with climate change is the result of excess greenhouse gas emissions from another country causing losses and damages in its jurisdiction. In the absence of conclusive evidence, the scientific answer is reduced to probabilistic causation. This problem represents the characteristic of climate change and its adverse effects, which cannot be verified, at least at this moment, the causal link that demonstrates the connection of the damage occurred in one place with the emission of greenhouse gases in another. Furthermore, the effects are not uniformly distributed worldwide, the most affected are the groups of scarce financial and technological resources in the developing countries. ${ }^{41}$ On this view, Pages and Heyward remark that the compensatory models are vulnerable to the objection that despite the fact that human activity have caused current climate change, it is not possible to prove that anthropogenic climate change was uniquely responsible for any particular loss or damage. ${ }^{42}$ Those who must receive compensation must prove that the losses and damages would not have occurred had it not been for the actions of the compensation providers. ${ }^{43}$

In these conditions, attributing damage responsibility to climate change faces two major difficulties: First, how does a physical event such as a flood needs to be attributed to climate change. Second, how are the consequences of these physical events on individuals, societies and ecosystems to be attributed. The difficulty of characterizing injuries and causal connections excludes the existence of reparation and compensation obligations. ${ }^{44}$ In a defensive manner, a compensation claim is more likely to be successful in establishing liability according to the amount of emissions a country has made, this means that states contribute to climate change in different proportions, according to the emissions made. ${ }^{45}$ From a theoretical perspective, countries that emit most of the greenhouse gases should compensate victims of their past and present activities which resulted in climate modification. Simultane-

41 Letcher Trevor M., Gimate Change, Observed Impacts on Planet Earth 4 (Elsevier) (2009).

42 Edward A Page \& Clare Heyward, Compensating for Climate Change Loss and Damage, supra note 26 .

43 Barbara Saxler et al., International Liability for Transboundary Damage Arising from Stratospheric Aerosol Injections, 7 Law, Innovation and Technology 112, 147 (2015).

44 Benoit Mayer, The International Law on Climate Change, supra note 27.

45 John Knox, Linking Human Rights and Climate Change at the United Nations, 33 Harvard Environmental Law Review 477, 498 (2009). John H. Knox, Climate Change and Human Rights Law, 50 Virginia Journal of International LaW 164, 218 (2009). 
ously, these countries should reduce and stop activities that transform the climate system. ${ }^{46}$

Furthermore, the causes and climate effects materialize in a transboundary environment, they are not limited to specific places. Actions that are carried out in one country could have negative repercussions in others as well. In this respect, Bridget Lewis says that the causes and effects of climate change generally operate internationally. ${ }^{47}$ As was previously mentioned, this represents the challenge of proving that the activities carried out in the jurisdiction, and under the control of one country has crossed its borders and affected human rights as well as the environment of other countries as well. The objective is to demonstrate that countries have violated the general principles of law where "States have the responsibility to ensure that activities within their jurisdiction or control do not cause damage to the environment of other States or of areas beyond the limits of national jurisdiction". ${ }^{48}$ Therefore, public international law must offer an efficient regulatory framework to address these issues, especially to regulate climatic impacts that are reflected in different times and places, exacerbating the problems that already existed (pre-existing challenges). ${ }^{49}$

Considering that States have more control of emissions in their jurisdictions,${ }^{50}$ some climate disputes are more likely to succeed than others. For instance, trials to reduce emissions, as Urgenda vs Netherlands, are more likely to thrive where the government (Dutch) was forced to reduce its emissions. However, countries do not have control of the consequences of their emissions inside or outside their territories. Therefore, trials to demand the compensation of human rights violation or ecosystems damage related to climate change are less likely to succeed. ${ }^{51}$ As in the case of the Inuit petition before the Inter-American Commission on Human Rights, where it was alleged that the emissions of the United States of America caused changes in the environmental conditions of the Inuit regions, such as the alteration of ice and snow patterns, which affected the ecosystems and human rights of Inuit people. At the same time, it has already been demonstrated that approximately from 1751 onwards, corporations such as Chevron, ExxonMobil, Saudi Aramco, BP and Gazprom head the list of the main industrial emitters of

46 Ian W. H. Parry, Fiscal Interactions and the Case for Carbon Taxes over Grandfathered Carbon Permits, 19:3 Oxford Review of Economic Policy 385, 399 (2003).

47 Id.

48 U. N. The Rio Declaration on Environment and Development principle 2 (1992). U. N. Convention on Biological Diversity article 3 (1992).

49 Benoit Mayer, The International Law on Climate Change, supra note 27.

50 Bridget Lewis, Environmental Human Rights and Climate Change. Current StaTus And Future Prospects, supra note 36 at 185.

51 Id. at 152. 
CO2 and other elements such as methane, ${ }^{52}$ therefore, it is convenient to answer the following question: Are these these companies obliged to repair damages and losses related to climate change? The answer to this question is linked to market failures of certain economic activities that emit greenhouse gases, as well as activities of economic actors who add a financial burden to society by not paying the costs of these negative externalities. ${ }^{53}$

One way of including costs of loss and damage related to greenhouse gas emissions is through government regulations to internalize externalities. According to Spyridon Stavropoulos et al., regulations to internalize the externalities of economic activities can be grouped into two categories: commandand-control instruments and market-based instruments. ${ }^{54}$ The first category are regulations to control pollution, in which governments can impose sanctions or rewards to those who comply or breach the law. The second category is directed towards polluters, to pay the social and environmental costs of their activities. These regulations can be applied ex post or ex ante. ${ }^{55}$

In conclusion, the questions about which are the most adequate mechanisms of compensation for damages and climatic losses, are subject to the problem of attribution and causality, as a result from the characteristics of how these damages and losses are manifested in time and space. It is also taken in consideration the way in which they have been caused through diffuse pollution. Therefore, the costs that polluters must pay are lower than those society has to pay.

\section{The Theory of Human Rights and Compensation for Damages and Losses Related to Climate Change}

This section will discuss the advantage and difficulties of addressing damage and climate loss through the perspective of the human rights theory, which has the purpose of supporting people who suffer the impacts of climate change. Also, it will be analyzed how States must comply with their obligations to protect human rights from the adverse effects of climate change. Considering that if human rights affected by climate change are guaranteed under international human rights law, and by many constitutions, then a claim on climate issues could be based on the objective of fulfilling, protecting or guaranteeing these rights from the adverse effects related to climate change. ${ }^{56}$

52 Säde Hormio, Can Corporations Have (Moral) Responsibility Regarding Climate Change Mitigation?, 20 Ethics, Policy \& Environment 314, 332 (2017).

53 Id.

54 Spyridon Stavropoulos et al., Environmental Regulations and Industrial Competitiveness: Evidence from China, 50 Applied Economics 1,378, 1,394 (2018).

55 Jonathan Baert Wiener, Global Environmental Regulation: Instrument Choice in Legal Context, 108 The Yale LaW Journal 677, 800 (1999).

56 Bridget Lewis, Environmental Human Rights and Climate Change. Current StaTus And Future Prospects, supra note 36 at 152. 
The effects of climate change violate human rights, such as the right to health, food, water, housing, physical security, freedom of movement, selfdetermination, and even the right to life, all of them affected through environmental changes as a consequence of climate change. Remarkably, most human rights are guaranteed under important human rights treaties, with universal memberships, and by the constitutions of many countries (rights held by groups or by individuals, with different type of duties for States). Therefore, human rights theory offers a good opportunity to focus the international debate on climate change based on the priority of these rights, and to add pressure on the responsible parties. However, to prove injuries to human rights due to climate change does not determine who are responsible, and it is not a guarantee for an adequate compensation.

Regarding the incorporation of human rights principles in international treaties of climate change, Bridget Lewis argues that during the negotiations of the Paris Agreement in 2015, many States and non-governmental organizations proposed a strong reference of human rights in the text of the Agreement. ${ }^{57}$ However, under the influence of the powerful developed countries, this proposal gradually lost strength, and the final text of the Agreement only includes a provision for States "... action to address climate change, respect, promote and consider their respective obligations on human rights, the right to health, the rights of indigenous peoples, local communities, migrants, children, persons with disabilities and people in vulnerable situations and the right to development, as well as gender equality, empowerment of women and intergenerational equity". ${ }^{58}$ As Lewis argues, this appears in the preamble of the agreement and not in the operative part of the text, so the contribution of the Agreement to human rights and climate change is minimal. ${ }^{59}$ Theodor Rathgeber says that to integrate the climate with the human rights regime to protect vulnerable groups it is important to consider several dimensions, of which the author mentions:

1) The potential impact dimension: involves assessing the consequences of climate change, especially among members of vulnerable population groups.

2) The dimension of the mechanisms and instruments with which the consequences of climate change can be accurately identified in living conditions, and through which a litigation resolution process can be induced.

3) The dimension of adequate prioritization: it refers to both the urgency and the existential threat, in view of the irreversibility of certain meteorological processes that hinder access to resources, not guaranteeing

\footnotetext{
57 Id.

58 The Paris Agreement art. 8, Dec. 12, 2015, U.N.F.C.C.C/CP.

59 Bridget Lewis, Environmental Human Rights and Climate Change. Current StaTus ANd Future Prospects, supra note 36 at 154.
} 
the subsistence and way of life of vulnerable groups facing the adverse effects associated with climate change. ${ }^{60}$

Furthermore, States have responsibilities over their citizens or those under their jurisdiction, without being accountable for those outside their jurisdiction. In this aspect, John Knox says that regardless of whether or not a State contributed or not to climate change, it does not exempt it from the responsibility for taking adaptation and mitigation measures. A State even has an obligation to reduce emission levels. ${ }^{61}$

However, this does not mean that the strongest obligation to reduce emissions is to those countries with less pollution.

The arguments mentioned in the previous paragraph, are in accordance with the distribution of the costs of managing the effects of climate change that developed countries must pay for their continuous and cumulative emissions. Edward A. Page mentioned three sub-principles to consider for supporting people affected by climate change; 1) Countries must compensate identifiable victims. 2) Countries should reduce the activities that transform the climate system. 3) Countries should fund measures to reduce the human costs of climate impacts that can no longer be avoided. ${ }^{62}$

Regarding the assessment of contributions to the problem of the costs of climate change effects, the polluter pays principle (PPP) is an economic-legal instrument that contributes to global responsibility towards the effects of climate change. Furthermore, this principle has a different perspective compared to that established in Article 3.1 of the United Nations Framework Convention on Climate Change, in relation to "common but differentiated responsibility based on respective capabilities". ${ }^{63}$ Therefore, from an economic perspective, the polluter pays principle that is applied through a variety of economic instruments, contributes to internalize the costs of environmental damages and losses, and it is important to protect and provide human rights affected by the effects of advertising related to climate change. ${ }^{64}$

In addition, the polluter pays principle improves current adaptation efforts, which fall into the category of what are called incremental adaptations: "Incremental adaptation represents familiar strategies of small changes to existing practices so as to sustain the functioning of existing socio-ecological

60 Theodor Rathgeber, Los Derechos Humanos ¿Guía en la lucha contra el cambio climático?, 23 Policy Paper Friedrich Ebert Stiftung, Fes-Ildis 1, 34 (2012).

61 Bridget Lewis, Environmental Human Rights and Climate Change. Current StaTus AND Future Prospects, supra note 36 at 178.

62 Edward A. Page, Distributing the Burdens of Climate Change, 17 Environmental Politics 556,575 (2008).

63 United Nations Framework Convention on Climate Change art. 3.1, Jun. 4, 1992, U.N.

64 Mizan R. Khan, Polluters-Pays-Principle: The Cardinal Instrument for Addressing Climate Change, 4 (3)Journal Laws 638, 653 (2015) 
systems under climate change". ${ }^{65}$ However, these adaptation policies are, in some circumstances, insufficient to address transformational changes, which require new innovative strategies and government intervention, such as addressing the losses and harms of climate change as a third applicable aspect following the policies of mitigation and adaptation.

Lastly, some human rights can be interpreted as a cover of climate change consequences. For instance, the right to life in the case of an escalation of extreme weather events; the rights of indigenous people, the right to peace and security; the right to health (relevant when diseases increase); as many others. In the context of litigation, the approach of human rights could provide or found jurisdiction to determine what is the applicable law. Correspondingly, it is necessary to apply changes in the law or enactment news incorporating specific obligations, beyond international cooperation, for compensation and repair for damage and climate loss. ${ }^{66}$ It is important to bear in mind that the result of increased emissions of greenhouse gases of developed countries is only explained to society through the research from different sciences. ${ }^{67}$ Therefore, the possibility of addressing the challenge of climate change from an environmental and human rights perspective will be more likely to succeed incorporating scientific knowledge into the law.

\section{Conclusions}

International and national law must have a harmonious vision of climate change to develop a multisectoral approach to face challenges such as migration, food security, and humanitarian crises, all exacerbated due to global warming, extreme weather events, water stress, among others. In this sense, and aware that the current climate change is human-induced, it is possible to mention some climate responsibilities: the responsibility to limit or reduce the emission of greenhouse gases, the responsibility to maintain the decline of greenhouse gases, the responsibility to prevent climate damage, and the responsibility to invest for adaptation actions. However, these responsibilities are insufficient to pay the adverse effects of climate change. Therefore, it is also necessary to determine roles and responsibilities in compensation.

Attribution and causality in the context of climate change provide arguments to indicate critical points to prioritize financial support for damage and

65 Catrien J. A. M. Termeer et al., Transformational Change: Governance Interventions for Climate Change Adaptations from a Continuous Change Perspective, 60 (4) Journal of Environmental PlanNING ANd MaNagEMENT 558, 576 (2017).

66 Richard Lord et aL., Cimimate Change Liability 38, 40 (Cambridge University Press) (2011).

67 Jon Naustdalslid, Climate Change-The Challenge of Translating Scientific Knowledge into Action, 18 (3) International Journal of Sustainable Development \& World Ecology 243, 252 (2011). 
climate loss. Additionally, countries have a specific responsibility according to the amount of historical and current emissions (climate debt). Regarding the advantage of the human rights approach in the context of climate change, it should be interpreted as a protection towards the adverse effects of climate change as human rights violations.

Climate change issue of loss and damage is complex in its historical, generational, economic, ethical, philosophical, moral, and legal dimensions. Therefore, it is important to be aware of climate science history. Two important facts have been established by the climate sciences:

1) The atmosphere regulates the climate system and protects our planet, and it has negative consequences for ecosystems and humans when the greenhouse effect is altered.

2) Greenhouse gases have decomposed the chemical composition of the atmosphere, especially because of the burning of fossil fuels that increases the atmospheric Carbon Dioxide. These findings support the attribution and causal link theory of loss and damage related to climate change.

Finally, there is a challenge towards strengthening sufficient capitalization of international climate financial mechanisms. Due to the threats of certain developed countries to withdraw from important international treaties such as the Paris Agreement, a variety of financing institutions in the field of climate finance governance are losing billions of US dollars. 